\title{
EKSPRESI CD30 PADA PASIEN DIFFUSE LARGE B-CELL LYMPHOMA DI RSUP DR. KARIADI SEMARANG
}

\author{
Jessica Winoto"; Udadi Sadhana²; Dik Puspasari²; Siti Amarwati²; Devia Eka Listiana²; Hermawan \\ Istiadi $^{2}$ \\ Residen Departemen Patologi Anatomi, Fakultas Kedokteran Universitas Diponegoro, Semarang, \\ Indonesia ${ }^{1}$; Staf pengajar Departemen Patologi Anatomi, Fakultas Kedokteran Universitas \\ Diponegoro, Semarang, Indonesia ${ }^{2}$
}

Corresponding email: jessicawin11@gmail.com

\begin{abstract}
Abstrak
Latar Belakang: Diffuse Large B-Cell Lymphoma (DLBCL) merupakan penyakit heterogen dengan berbagai morfologi, sifat biologi dan klinis, yang memiliki respon terapi bervariasi. Beberapa penelitian melaporkan adanya ekspresi CD30 pada DLBCL berhubungan dengan ketahanan hidup yang lebih baik. Namun hal ini masih perlu dilakukan penelitian lebih lanjut. Tujuan penelitian ini untuk mengevaluasi ekspresi CD30 pada pasien DLBCL di RSUP Dr. Kariadi.

Metode penelitian: Penelitian ini mengevaluasi ekspresi CD30 pada 35 pasien DLBCL di RSUP Dr. Kariadi periode Januari 2017 hingga Desember 2017 menggunakan cut off $>0 \%$. Data klinik yang diambil yaitu usia saat terdiagnosis, lokasi tumor, stadium penyakit, subtipe sel asal, dan ketahanan hidup 2 tahun. Analisis data menggunakan uji chi square.

Hasil: Dari 35 kasus, CD30 diekspresikan oleh 13 kasus (37.1\%). Ekspresi CD30 lebih tinggi pada pasien dengan usia $\geq 60$ tahun $(P=0.03)$, lokasi ekstranodal $(P=0.78)$, stadium awal $(P=0.89)$, dan subtipe non-GCB $(P=0.97)$. Kelompok $C D 30$ positif memiliki ketahanan hidup yang lebih baik dibandingkan $\mathrm{CD} 30$ negatif $(\mathrm{P}=0.90)$.

Kesimpulan: Ekspresi CD30 memiliki hubungan yang bermakna dengan usia $\geq 60$ tahun. Pasien DLBCL dengan CD30 positif memiliki ketahanan hidup yang lebih baik dibandingkan CD30 negatif, namun tidak bermakna.
\end{abstract}

Kata Kunci : CD30, DLBCL, ketahanan hidup keseluruhan 


\title{
CD30 EXPRESSION IN DIFFUSE LARGE B-CELL LYMPHOMA PATIENTS IN KARIADI GENERAL HOSPITAL SEMARANG
}

\author{
Jessica Winoto'; Udadi Sadhana²; Dik Puspasari²; Siti Amarwati2; Devia Eka Listiana²; Hermawan \\ Istiadi $^{2}$
}

Resident of Anatomical Pathology Department, Faculty of Medicine Diponegoro University, Semarang Indonesia ${ }^{1}$; Lecturer of Anatomical Pathology Department, Faculty of Medicine Diponegoro University, Semarang Indonesia ${ }^{2}$

Corresponding email: jessicawin11@gmail.com

\begin{abstract}
Background: Diffuse Large B-Cell Lymphoma (DLBCL) is a heterogenous disease containing morphology, biologically dan clinically distinctive subgroups that show variable response to therapy. Many studies showed that CD30 expression in DLBCL is associated with superior overall survival. However, prognostic value of CD30 expression in DLBCL still needs further studies. The aim of this study was to determine the expression of CD30 in DLBCL patients in Kariadi General Hospital.

Methods: This study identified CD30 expression in 35 cases of DLBCL diagnosed between January 2017 and December 2017, using cut off values $>0 \%$. Clinical data collected including age of diagnosis, tumour location, stage of disease, cell of origin subtype, and two-year overall survival. Data were analyzed using chi square test.

Results: $C D 30$ expression was found in $13(37.1 \%)$ cases. $C D 30$ positivity was higher in age $\geq 60$ years $(P=0.03)$, extranodal location (0.78), early stage $(P=0.89)$, and non-GCB subtype $(P=0.97)$. CD30-positve DLBCL had a better survival than CD30-negative DLBCL $(P=0.90)$.

Conclusion: $C D 30$ positivity was significantly associated with age $\geq 60$ years. CD30-positve $D L B C L$ had a better survival than CD30-negative DLBCL, but not significant.
\end{abstract}

Keywords: CD30. DLBCL, overall survival

\section{LATAR BELAKANG}

Limfoma dibagi menjadi 2 kelompok utama, yaitu limfoma Hodgkin dan limfoma non-Hodgkin (LNH). Lebih dari 90\% LNH merupakan limfoma yang berasal dari sel $\mathrm{B}$ matur. ${ }^{1-3} \mathrm{LNH}$ merupakan keganasan hematologi yang paling sering terjadi di dunia. Di Indonesia, LNH menempati peringkat ke 7 pada kasus keganasan yang paling sering ditemukan.4,5 Tipe LNH yang terbanyak, yaitu diffuse large B-cell lymphoma (DLBCL). ${ }^{2,6-9}$ DLBCL merupakan neoplasma sel limfoid B berukuran medium atau besar, memiliki inti berukuran sama atau lebih besar dari inti makrofag normal, atau lebih besar 2 kali ukuran inti limfosit normal, dengan pola difus. $2,6,10,11$

DLBCL terjadi sekitar 25-35\% kasus LNH pada negara maju, dan terdapat persentase lebih tinggi pada negara yang sedang berkembang. ${ }^{2,7,8}$ DLBCL lebih sering terjadi pada usia tua dan lakilaki. DLBCL dapat mengenai daerah nodal maupun ekstranodal.2,6,10-12 Pengobatan standar pada pasien DLBCL yaitu rituximab, cyclophosphamide, doxorubicin, vincristine, dan prednisone (R-CHOP), namun sekitar $40 \%$ pasien DLBCL mengalami relaps atau refrakter. ${ }^{11,13-16}$ 
Secara molekular, klasifikasi DLBCL dilakukan melalui gene expression profiling (GEP) dan pemeriksaan imunohistokimia menjadi subtipe Germinal Center B-cell (GCB) dan Activated B-cell (ABC/non-GCB).,2, 17-19 Alat prognostik utama yang digunakan pada pasien DLBCL yaitu International Prognostic Index (IPI), meliputi faktor usia, stadium tumor (Ann Arbor staging), kadar serum lactate dehydrogenase (LDH), status performa pasien berdasarkan Eastern Cooporative Oncology Group (ECOG), dan jumlah area ekstranodal yang terkena. ${ }^{16,20-23}$

CD30, disebut juga tumour necrosis factor receptor super family 8 (TNFRSF8), pertama kali diidentifikasi pada sel Hodgkin Reed-Stenberg limfoma Hodgkin klasik, selanjutnya pada limfoma sel besar anaplastik. CD30 juga dapat diekspresikan oleh DLBCL. ${ }^{24-27}$ Brentuximab vedotin, agen yang ditargetkan untuk limfoma dengan CD30 positif, dapat memberikan manfaat pada pasien DLBCL dengan CD30 positif, terutama setelah mengalami relaps atau refrakter terhadap pengobatan standar. $26,28-30$

Banyak penelitian melaporkan adanya ekspresi CD30 pada pasien DLBCL memiliki prognosis lebih baik dibandingkan dengan CD30 negatif.8,25,31,32 Penelitian lain menyebutkan bahwa ekspresi CD30 sebagai faktor prognostik pada pasien DLBCL masih kontroversial. ${ }^{29}$

\section{METODE}

Penelitian ini merupakan penelitian observasional analitik dengan rancangan cross sectional. Penelitian dimulai sejak ethical clearance dan ijin penelitian keluar hingga jumlah sampel terpenuhi, yaitu blok parafin pasien yang telah didiagnosis secara histopatologi dan imunohistokimia sebagai DLBCL di RSUP Dr. Kariadi periode Januari 2017 - Desember 2017. Setelah sampel terkumpul, dilakukan pengambilan data dari rekam medik, meliputi usia saat terdiagnosis, lokasi tumor, stadium penyakit, subtipe sel asal DLBCL, dan ketahanan hidup pasien 2 tahun pasca diagnosis.

Kriteria inklusi pada penelitian ini yaitu memiliki rekam medik dengan data klinik yang lengkap, serta memiliki blok parafin yang mengandung jaringan cukup untuk dilanjutkan pemeriksaan imunohistokimia CD30. Kriteria eksklusi pada penelitian ini yaitu sampel yang tidak sesuai dengan diagnosis histopatologi pada saat dilakukan review. Analisis data dilakukan menggunakan program SPSS (Statistical Product and Service Solution). Untuk mendapatkan hubungan antar variabel, digunakan uji chi square dengan derajat kemaknaan $p<0.05$. 


\section{HASIL}

\section{Karakteristik Sampel Penelitian}

Penelitian ini menggunakan sampel pasien di RSUP Dr. Kariadi selama periode Januari 2017 hingga Desember 2017 yang telah didiagnosis secara histopatologi dan imunohistokimia sebagai DLBCL, disertai subtipe sel asal. Sampel penelitian dipilih secara consecutive sampling, dan didapatkan 35 sampel. Data klinikopatologik pasien dapat dilihat pada Tabel 1.

Dari 35 pasien, 18 diantaranya adalah laki-laki, dengan ratio laki-laki : perempuan yaitu 1.06:1. Usia rata-rata saat terdiagnosis yaitu 52 tahun (24 hingga 77 tahun). Sebagian besar pasien didiagnosis pada usia kurang dari 60 tahun (74.3\%), memiliki lokasi tumor ekstranodal primer (74.3\%), meliputi colon, ileum, hepar, lien, ginjal, cavum nasi, mediastinum, tonsil, rongga hidung, palpebra, konjungtiva, sistem saraf pusat, dan femur. Lokasi tumor nodal ditemukan di kelenjar getah bening colli, inguinal, aksila, yang dapat tunggal maupun multipel. Berdasarkan Ann Arbor staging, sebagian besar pasien didiagnosis pada stadium awal (60\%). Berdasarkan subtipe molekuler sel asal menggunakan algoritma Hans, pasien lebih banyak memiliki subtipe non-GCB (54.3\%). Sebanyak 22 pasien meninggal (62.9\%) setelah dilakukan follow up dalam waktu 2 tahun pasca diagnosis.

Tabel 1. Data Klinikopatologik Pasien DLBCL $(n=35)$

\begin{tabular}{lcc}
\hline & Frekuensi & Prosentase \\
\hline Kategori usia & & \\
$\quad$ - <60 Tahun & 26 & $74.3 \%$ \\
$\quad$ - $\geq 60$ Tahun & 9 & $25.7 \%$ \\
Lokasi & & \\
- Nodal & 9 & $25.7 \%$ \\
- Ekstranodal & 26 & $74.3 \%$ \\
Stadium & & \\
- Awal (I \& II) & 21 & $60 \%$ \\
- Lanjut (III \& IV) & 14 & $40 \%$ \\
Subtipe molekuler sel asal & & \\
- GCB & 16 & $45.7 \%$ \\
- Non-GCB & 19 & $54.3 \%$ \\
Ketahanan hidup 2 tahun & & \\
- Hidup & 13 & $37.1 \%$ \\
- Mati & 22 & $62.9 \%$ \\
\end{tabular}




\section{Hubungan Ekspresi CD30 dengan Profil Klinis Pasien DLBCL}

Dari total 35 pasien, didapatkan 13 pasien (37.1\%) memberikan hasil CD30 positif, dengan 7 pasien (53.8\%) terdiagnosis pada usia kurang dari 60 tahun, 10 pasien $(76.9 \%)$ memiliki lokasi ekstranodal, 8 pasien (61.5\%) pada stadium awal, 7 pasien (53.8\%) subtipe non-GCB, dan 5 pasien (38.5\%) masih bertahan hidup dalam waktu 2 tahun pasca diagnosis. Pemeriksaan imunohistokimia CD30 dilakukan oleh 2 spesialis Patologi Anatomik secara blinded. CD30 memberikan hasil positif jika diekspresikan oleh sel tumor lebih dari 0\%. Penampakan hasil negatif dan positif CD30 pada DLBCL dapat dilihat pada Gambar 1.

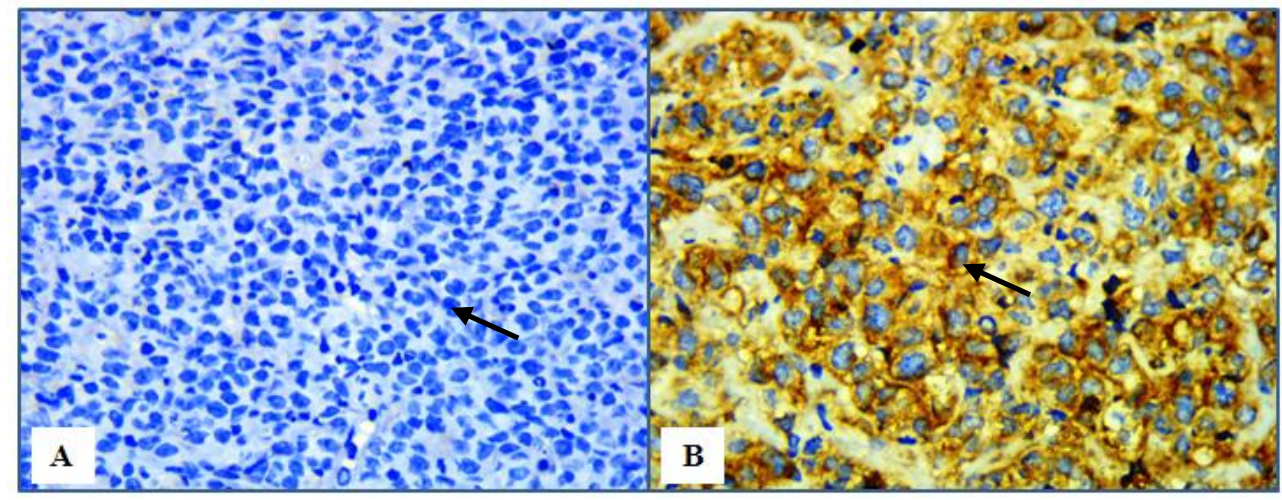

Gambar 1. Ekspresi CD30 pada DLBCL. (A) Ekspresi CD30 negatif, HE,100x (B) Ekspresi CD30 positif pada membran sel, HE,400x. (Sumber: sampel penelitian)

Berdasarkan uji chi square, CD30 memiliki hubungan yang bermakna dengan usia saat terdiagnosis lebih besar sama dengan 60 tahun $(P=0.03)$. CD30 positif lebih tinggi diekspresikan oleh lokasi tumor ekstranodal $(P=0.78)$, stadium awal $(P=0.89)$, dan subtipe non-GCB ( $P=0.97)$, namun tidak memiliki hubungan yang bermakna. Pasien DLBCL dengan CD30 positif memilii ketahanan hidup yang lebih baik dibandingkan $C D 30$ negatif $(P=0.90)$. Data ekspresi $C D 30$ terhadap profil klinis pasien DLBCL dapat dilihat pada Tabel 2. Perbandingan ketahanan hidup 2 tahun pasien DLBCL dengan CD30 positif dan CD30 negatif dapat dilihat pada Gambar 2. 
Tabel 2. Ekspresi CD30 terhadap Profil Klinis Pasien DLBCL

\begin{tabular}{lrrr}
\hline & CD30 + & CD30 - & P \\
\hline Ekspresi CD30 & $13(37.1 \%)$ & $22(62.9 \%)$ & \\
& & & 0.03 \\
Kategori usia & & & \\
$-<60$ Tahun & $7(53.8 \%)$ & $19(86.4 \%)$ & 0.78 \\
- $\geq 60$ Tahun & $6(46.2 \%)$ & $3(13.6 \%)$ & \\
Lokasi & & & 0.89 \\
- Nodal & $3(23.1 \%)$ & $6(27.3 \%)$ & \\
- Ekstranodal & $10(76.9 \%)$ & $16(72.7 \%)$ & 0.97 \\
Stadium & & & \\
- Awal (I \& II) & $8(61.5 \%)$ & $13(59.1 \%)$ & \\
- Lanjut (III \& IV) & $5(38.5 \%)$ & $9(40.9 \%)$ & \\
Subtipe molekuler sel asal & & & \\
- GCB & $6(46.2 \%)$ & $10(45.5 \%)$ & \\
- Non-GCB & $7(53.8 \%)$ & $12(54.5 \%)$ & \\
\hline
\end{tabular}

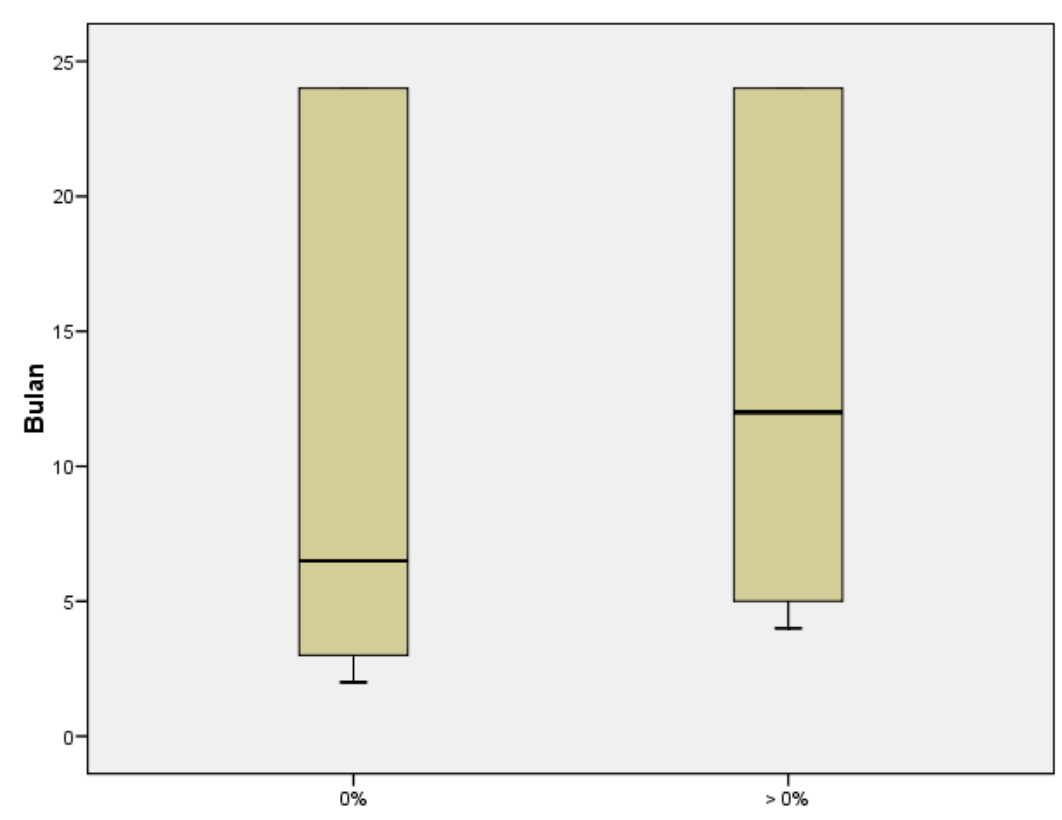

Gambar 2. Ekspresi CD30 terhadap ketahanan hidup pasien DLBCL. 


\section{PEMBAHASAN}

DLBCL merupakan penyakit heterogen dengan berbagai morfologi, imunofenotipe, klinis dan biologi, yang dapat memberikan respons terapi bervariasi. ${ }^{18,19,33-35}$ Pada penelitian ini, CD30 diekspresikan oleh 13 kasus (37.1\%) menggunakan cut off di atas $0 \%$. Hasil ini sesuai dengan penelitian-penelitian sebelumnya, di mana CD30 diekspresikan oleh 24-41\% kasus DLBCL menggunakan cut off di atas $0 \%{ }^{28,36-38}$ Ekspresi CD30 lebih dari $0 \%$ pada sel tumor berhubungan dengan ketahanan hidup yang lebih baik, serta dapat memberikan respon terhadap terapi target, sehingga cut off di atas $0 \%$ menjadi optimal untuk digunakan dalam mengidentifikasi ekspresi CD30 pada pasien DLBCL. ${ }^{37,39,40}$

Ekspresi CD30 berhubungan secara bermakna dengan kelompok usia lebih besar sama dengan 60 tahun. Hasil ini berbeda dengan penelitian-penelitian sebelumnya yang melaporkan bahwa ekspresi CD30 berhubungan dengan usia lebih muda yaitu kurang dari 60 tahun, di mana usia lebih muda memiliki angka komorbiditas lebih rendah dan toleransi lebih baik terhadap gejala penyakit. Perbedaan ini dapat diakibatkan oleh variasi dalam sampel penelitian, maupun perbedaan ras dan geografi. Penelitian-penelitian sebelumnya dilakukan pada penduduk Spanyol dan Amerika, dengan jumlah sampel yang digunakan lebih banyak, dan sampel lebih homogen, di mana pasien dengan infeksi Epstein Barr-Virus (EBV), kondisi imunodefisiensi, riwayat limfoma sel B derajat rendah, limfoma mediastinal primer maupun gangguan limfoproliferatif post transplant DLBCL tidak diikutsertakan dalam penelitian. ${ }^{37,41}$

Ekspresi CD30 lebih tinggi pada lokasi tumor ekstranodal, namun tidak memiliki hubungan yang bermakna. Alasan CD30 lebih tinggi diekspresikan oleh kelompok tumor ekstranodal masih belum jelas. Hal ini dapat dipengaruhi oleh karakteristik sampel, di mana sebagian besar tumor memiliki lokasi ekstranodal (74.3\%). Penelitian sebelumnya yang dilakukan pada pasien DLBCL di Indonesia, juga memiliki karakteristik sampel penelitian dengan lokasi tumor ekstranodal lebih banyak. Beberapa penelitian sebelumnya yang mengevaluasi CD30 terhadap pasien DLBCL, menggunakan kategori kelompok keterlibatan ekstranodal 0-1 dan 2 tempat atau lebih, dengan hasil ekspresi CD30 lebih tinggi pada keterlibatan ekstranodal 0-1 tempat, namun tidak bermakna. $28,33,35,42$

Ekspresi CD30 lebih tinggi pada stadium awal, namun tidak memiliki hubungan yang bermakna. Hasil ini berbeda dengan penelitian-penelitian sebelumnya, yang menunjukkan ekspresi 
CD30 lebih tinggi pada DLBCL stadium lanjut tetapi tidak bermakna. Kondisi ini dapat dipengaruhi oleh perbedaan ras dan geografi pada populasi sampel penelitian, serta waktu follow up, di mana penelitian sebelumnya dilakukan pada populasi penduduk Kanada dan Amerika, pasien de novo DLBCL, tidak terinfeksi HIV, tidak memiliki subtipe DLBCL lain seperti limfoma mediastinal primer, DLBCL sistem saraf pusat, limfoma testikular dan intravaskular, riwayat limfoma derajat rendah, maupun gangguan limfoproliferatif post transplant, dan menggunakan waktu follow up lebih dari 4 tahun. ${ }^{29,35,37}$ Karakteristik sampel pada penelitian ini juga didapatkan lebih banyak pada stadium awal $(60 \%)$.

Ekspresi CD30 lebih tinggi pada subtipe non-GCB, namun tidak memiliki hubungan yang bermakna. Hasil ini selaras dengan penelitian-penelitian sebelumnya di mana CD30 positif lebih banyak didapatkan pada subtipe non-GCB. Hal ini berkaitan dengan pemeriksaan ekspresi gen yang menunjukkan ekspresi mRNA CD30 lebih sering ditemukan pada subtipe non-GCB dibandingkan GCB. ${ }^{37,41,43,44}$

Kelompok pasien DLBCL dengan CD30 positif memiliki ketahanan hidup lebih baik dibandingkan CD30 negatif, namun tidak bermakna. Hasil ini selaras dengan penelitian-penelitian sebelumnya, di mana pasien DLBCL dengan CD30 positif memiliki ketahanan hidup lebih baik. Pada profil ekspresi gen DLBCL dengan CD30 positif, terjadi peningkatan aktifitas death receptor FAS dan downregulation beberapa onkogen, seperti CDCA7L, FZD5, dan DTX. Selain itu, terjadi peningkatan aktifitas beberapa gen yang mengkode regulator negatif jalur NF-kB dan masa hidup limfosit, meliputi TNFAIP3, TNFRAIP6, TNIP2, TRAF1, DUSP4, NXN, SAMSN1, dan SOCS1, serta penurunan aktifitas beberapa gen yang mengkode sinyal reseptor sel $\mathrm{B}$ dan proliferasi sel $\mathrm{B}$, seperti $\lg H \mu, C D 72, P K C \beta$, SH2D3C, NF-ATC1, TCL1A, FOXP1, dan BACH2. Hal ini dapat menjadi dasar molekular yang berkaitan dengan ketahanan hidup lebih baik. ${ }^{25,35,36,45}$

Ada beberapa keterbatasan dalam penelitian ini. Sampel yang kami ambil hanya menggunakan kasus DLBCL yang sudah dilengkapi dengan subtipe sel asal. Penelitian ini belum mempertimbangkan adanya infeksi EBV, kondisi imunodefisiensi, maupun riwayat limfoma derajat rendah, yang dapat mempengaruhi ketahanan hidup pasien DLBCL. 


\section{KESIMPULAN DAN SARAN}

CD30 diekspresikan oleh 37.1\% kasus DLBCL di RSUP Dr. Kariadi, dan memiliki hubungan bermakna dengan usia yang lebih tua ( $\geq 60$ tahun). Lokasi ekstranodal, stadium awal, dan subtipe non-GCB memiliki ekspresi CD30 lebih tinggi. Pasien DLBCL dengan CD30 positif memiliki ketahanan hidup lebih baik dibandingkan CD30 negatif, namun tidak bermakna. Pada penelitian selanjutnya, diharapkan dapat menggunakan jumlah sampel yang lebih banyak dan waktu follow up lebih lama. Variabel lain yang dapat mempengaruhi ketahanan hidup pasien DLBCL, seperti infeksi EBV, juga dapat digunakan.

\section{DAFTAR PUSTAKA}

1. Goldblum JR, Lamps LW, McKenney JK, Myers JL. Rosai and Ackerman;s surgical pathology. $11^{\text {th }}$ ed. Philadelphia: Elsevier; 2018.

2. Swerdlow SH, Campo E, Harris NL, Jaffe ES, Pileri SA, Stein H, Thiele J, editors. WHO classification of tumours of haematopoetic and lymphoid tissues. Revised ${ }^{\text {th }}$ ed. IARC: Lyon; 2017.

3. Armitage JO, Gascoyne RD, Lunning MA, Cavalli F. Non-Hodgkin lymphoma. Lancet, 2017;390:298-310.

4. The Global Cancer Observatory. Cancer today. Lyon: IARC; 2019. Available from: https://gco.iarc.fr/today/fact-sheets-cancers.

5. Chihara D, Nastoupil LJ, Williams JN, Lee P, Koff JL, Flowers CR. New insights into the epidemiology of non-Hodgkin lymphoma and implications for therapy. Expert review of anticancer therapy. 2015 May 4;15(5):531-44.

6. Miranda RN, Khoury JD, Medeiros LJ. Atlas of lymph node pathology. New York: Springer; 2018.

7. Habara T, Sato Y, Takata K, Iwaki N, Okumura H, Sonobe H, et al. Germinal center B-cell-like versus non-germinal center B-cell-like as important prognostic factor for localized nodal DLBCL. Journal of Clinical and Experimental Hematopathology. 2012;52(2):91-9.

8. O'Malley DP, Auerbach A, Weiss LM. Practical applications in immunohistochemistry: evaluation of diffuse large B-cell lymphoma and related large B-cell lymphomas. Archives of Pathology and Laboratory Medicine. 2015 Sep;139(9):1094-107.

9. Ashton-Key M, Wright P, Wright D. Diagnostic lymph node pathology. $3^{\text {rd }}$ ed. Florida: CRC Press; 2016.

10. Leong ASY. A pattern approach to lymph node diagnosis. New York: Springer; 2011.

11. Medeiros LJ, Miranda RN. Diagnostic pathology lymph nodes and extranodal lymphomas. $2^{\text {nd }}$ ed. Philadelphia: Elsevier; 2018.

12. Ferry JA. The diversity of diffuse large B-cell lymphoma in extranodal sites: overview and update. J Hematopathol. 2014. 7(2):57-70. doi:10.1007/s12308-014-0202-7.

13. Xie Y, Pittaluga S, Jaffe ES. The histological classification of diffuse large B-cell lymphoma. Semin Hematol. 2015;52(2):57-66.

14. Hwang HS, Park CS, Yoon DH, Suh C, Huh J. High concordance of gene expression profilingcorrelated immunohistochemistry algorithms in diffuse large B-cell lymphoma, not otherwise specified. Am J Surg Pathol. 2014;38:1046-57. doi: 10.1097/PAS.0000000000000211.

15. Vaidya R, Witzig TE. Prognostic factors for diffuse large B-cell lymphoma in the R(X)CHOP era. Ann Oncol. 2014 Nov;25(11):2124-33. doi: 10.1093/annonc/mdu109.

16. Zhou Z, Sehn LH, Rademaker AW, Gordon LI, Lacasce AS, Crosby-Thompson A, et al. An enhanced International Prognostic Index (NCCN-IPI) for patients with diffuse large B-cell lymphoma treated in the rituximab era. Blood. 2014 Feb 6;123(6):837-42. doi: 10.1182/blood2013-09-524108. 
17. Boltežar L, Prevodnik VK, Perme MP, Gašljević G, Novaković BJ. Comparison of the algorithms classifying the $A B C$ and GCB subtypes in diffuse large B-cell lymphoma. Oncol Lett. 2018 May;15(5):6903-12. doi: 10.3892/ol.2018.8243.

18. Hsi ED. Update in large cell lymphoma: understanding the pathology report. Hematology. 2015(1):605-17. doi:10.1182/asheducation-2015.1.605.

19. Carbone A, Gloghini A, Kwong YL, Younes A. Diffuse large B cell lymphoma: using pathologic and molecular biomarkers to define subgroups for novel therapy. Ann Hematol. 2014. 93(8):1263-77. doi:10.1007/s00277-014-2116-y.

20. Liu Y, Barta SK. Diffuse large B-cell lymphoma: 2019 update on diagnosis, risk stratification, and treatment. Am J Hematol. 2019 May;94(5):604-16. doi: 10.1002/ajh.25460.

21. Rovira J, Valera A, Colomo L, Setoain X, Rodríguez S, Martínez-Trillos A, et al. Prognosis of patients with diffuse large $B$ cell lymphoma not reaching complete response or relapsing after frontline chemotherapy or immunochemotherapy. Ann Hematol. 2015. 94(5):803-12. doi:10.1007/s00277-014-2271-1.

22. Tilly H, Gomes da Silva M, Vitolo U, Jack A, Meignan M, Lopez-Guillermo A, et al. Diffuse large B-cell lymphoma (DLBCL): ESMO Clinical Practice Guidelines for diagnosis, treatment and follow-up. Ann Oncol. 2015 Sep;26 Suppl 5:v116-25. doi: 10.1093/annonc/mdv304.

23. Younes A. Handbook of lymphoma. Switzerland: Springer; 2016.

24. van der Weyden CA, Pileri SA, Feldman AL, Whisstock J, Prince HM. Understanding CD30 biology and therapeutic targeting: a historical perspective providing insight into future directions. Blood Cancer J. 2017 Sep 8;7(9):e603. doi: 10.1038/bcj.2017.85.

25. Hu S, Xu-Monette ZY, Balasubramanyam A, Manyam GC, Visco C, Tzankov A, et al. CD30 expression defines a novel subgroup of diffuse large B-cell lymphoma with favorable prognosis and distinct gene expression signature: a report from the International DLBCL Rituximab-CHOP Consortium Program Study. Blood. 2013 Apr 4;121(14):2715-24. doi: 10.1182/blood-2012-10-461848.

26. Dabbs DJ. Diagnostic immunohistochemistry: theranostic and genomic applications. $5^{\text {th }}$ ed. Philadelphia: Elsevier: 2019.

27. Tuffaha MSA, Guski H, Kristiansen G. Immunohistochemistry in tumor diagnostics. Germany: Springer; 2018.

28. Xu J, Oki Y, Saksena A, Desai P, Lin P, Tang G, et al. CD30 expression and prognostic significance in R-EPOCH-treated patients with diffuse large B-cell lymphoma. Hum Pathol. 2017 Feb;60:160-166. doi: 10.1016/j.humpath.2016.10.009.

29. Hao X, Wei X, Huang F, Wei $Y$, Zeng $H$, Xu L, et al. The expression of CD30 based on immunohistochemistry predicts inferior outcome in patients with diffuse large B-cell lymphoma. PLoS ONE. 2015;10(5):e0126615. doi:10.1371/journal.pone.0126615.

30. Xu ML, Gabali A, Hsi ED, Fedoriw Y, Vij K, Salama ME, et al. Practical approaches on CD30 detection and reporting in lymphoma diagnosis. Am J Surg Pathol. 2019. 1. doi:10.1097/pas.0000000000001368.

31. Li S, Young KH, Medeiros LJ. Diffuse large B-cell lymphoma. Pathology. 2018 Jan;50(1):7487. doi: 10.1016/j.pathol.2017.09.006.

32. Chan WC. CD30, another useful predictor of survival in DLBCL?. Blood. 2013;121:2582-2583. doi: https://doi.org/10.1182/blood-2013-02-481978.

33. Gong QX, Lu TX, Liu C, Wang Z, Liang JH, Xu W, et al. Prevalence and clinicopathologic features of CD30-positive de novo diffuse large B-cell lymphoma in Chinese patients: a retrospective study of 232 cases. Int J Clin Exp Pathol. 2015; 8(12):15825-35.

34. Salas MQ, Climent F, Domenech ED, Mercadal S, Paredes V, Oliveira AC, et al. CD30 expression in diffuse large B-cell lymphoma (DLBCL) correlates with non-GCB subtype but does not have prognostic impact in patients treated with first line R-CHOP/R-CHOP-like. Blood. 2016. 128(22):4209..

35. Slack GW, Steidl C, Sehn LH, Gascoyne RD. CD30 expression in de novo diffuse large B-cell lymphoma: a population-based study from British Columbia. $\mathrm{Br} J$ Haematol. 2014 Dec;167(5):608-17. doi: 10.1111/bjh.13085.

36. Wang XJ, Seegmiller AC, Reddy NM, Li S. CD30 expression and its correlation with MYC rearrangement in de novo diffuse large B-cell lymphoma. European Journal of Haematology. 2015. 97(1):39-47. doi:10.1111/ejh.12680.

37. Salas MQ, Climent F, Tapia G, DomingoDomènech E, Mercadal S, Oliveira AC, et al. Clinicopathologic features and prognostic significance of CD30 expression in de novo diffuse large B-cell lymphoma (DLBCL): results in a homogeneous series from a single institution. Biomarkers. 2019. doi:10.1080/1354750x.2019.1691656. 
38. Malysz J, Erdman P, Klapper J, Zhu J, Creer M, Bayerl MG. Clinical Implications of CD30 Expression in Aggressive B-Cell Lymphomas. Clinical Lymphoma Myeloma and Leukemia. 2016. 16(8):429-33. doi:10.1016/j.clml.2016.04.011.

39. Bartlett NL, Smith MR, Siddiqi T, Advani RH, O'Connor OA, Sharman JP, et al. Brentuximab vedotin activity in diffuse large B-cell lymphoma with CD30 undetectable by visual assessment of conventional immunohistochemistry. Leukemia \& Lymphoma. 2016. 58(7):1607-16.

40. Jacobsen ED, Sharman JP, Oki Y, Advani RH, Winter JN, Bello CM, et al. Brentuximab vedotin demonstrates objective responses in a phase 2 study of relapsed/refractory DLBCL with variable CD30 expression. Blood. 2015. 125(9):1394-1402. doi:10.1182/blood-2014-09598763.

41. Campuzano-Zuluaga G, Cioffi-Lavina M, Lossos IS, Chapman-Fredricks JR. Frequency and extent of CD30 expression in diffuse large B-cell lymphoma and its relation to clinical and biologic factors: a retrospective study of 167 cases. Leukemia \& Lymphoma. 2013. 54(11);2405-11.

42. Snak Y, Indrawati, Widayati K, Arfian N, Anggorowati N. Molecular subtypes, apoptosis and proliferation status in Indonesian diffuse large B-cell lymphoma cases. Asian Pac J Cancer Prev. 2018. 19 (1):185-91.

43. Collie AMB. Hill BT. Manilich EA, Smith MR, His ED. CD30 Immunohistochemical expression in diffuse large B-cell lymphoma is associated with decreased overall survival and the nongerminal center molecular subtype. Blood. 2013. 122(21):4318.

44. Gandhi S, Neppalli VT, Deeb G, Czuczman MS, Hernandez-llizatirurri FJ. Distinct CD30 Expression Patterns In Germinal Center B-Cell (GCB) and Non-GCB Diffuse Large B-Cell Lymphoma (DLBCL). Blood. 2013. 122 (21).

45. Kanemasa Y, Shimoyama T, Sasaki Y, Tamura M, Sawada T, Omuro Y, et al. Prognostic significance of CD30 expression in patients with diffuse large B-cell lymphoma. Annals of Oncology. 2017. 28(9). 